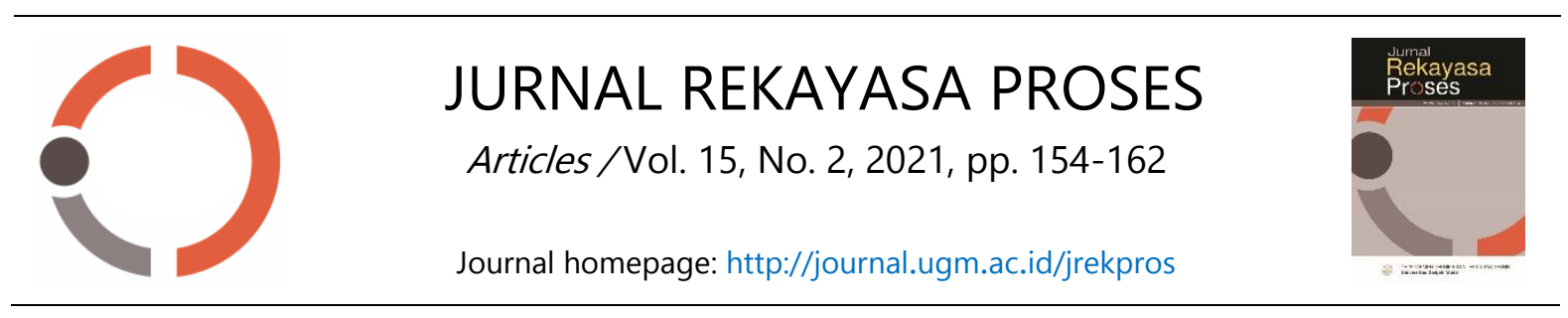

\title{
Separation of 6-Gingerol in Zingiber officinale Rubrum Varieties Using an Ultrasonic Assisted Extraction Method
}

\author{
Herliati Rahman, Satrio Nur Prambudi, Wahyu Endranaka \\ Chemical Engineering, Faculty of Industrial Technology, Jayabaya University \\ Jalan Raya Bogor km.28,8 Cimanggis Jakarta Timur \\ *Corresponding author: herliatimulyono@gmail.com
}

(Submission: 26-07-2021; Revision: 29-09-2021; Acceptance: 03-10-2021)

\section{A B S T R A C T}

Gingerol is a chemical compound found in red ginger, with pharmaceutical use as an analgesic drug. Generally, gingerol separation in ginger uses the Soxhlet extraction method, but this process has a weakness. It requires a long process and unsatisfactory yield. This research aims to study ultrasonic frequency effect on increasing gingerol yield in the extraction process. The variables studied were extraction times with variations of $30,60,90$, and 120 minutes. In addition, the ultrasonic effect was also observed with variations in the ultrasonic frequency of 40 and $50 \mathrm{kHz}$ compared to the solvent extraction method. This study used $70 \%(\mathrm{v} / \mathrm{v})$ ethanol as a solvent and an operating temperature of $50^{\circ} \mathrm{C}$ as fixed variables.

Furthermore, it used a rotary vacuum evaporator at a pressure of $350 \mathrm{mmHg}$ to separate the resulting gingerol extract. Qualitative sample analysis used Thin Layer Chromatography (TLC) and scanning electron microscope (SEM) while quantitative analysis used high-performance liquid chromatography (HPLC), Waters Alliance e2695 brand with X-Terra RP18 column $100 \mathrm{x}$ $4.6 \mathrm{~mm}$, five $\mu \mathrm{m}$ to determine the total gingerol extract. The results showed that ultrasonic power had a significant effect on the results obtained, with the highest yield was $24.71 \%$ at the ultrasonic frequency of $50 \mathrm{kHz}$ with an extraction time of 120 minutes.

Keywords: ginger; HPLC; rhizome; SEM; Soxhlet

\section{ABSTRAK}

Gingerol adalah senyawa kimia dalam jahe merah yang banyak digunakan sebagai bahan obat analgesik. Umumnya ekstraksi gingerol dalam jahe menggunakan metode ekstraksi Soxhlet. Namun proses ini memiliki kelemahan yaitu proses yang lama dan yield yang belum memuaskan. Tujuan dari penelitian ini adalah untuk mempelajari pengaruh frekuensi ultrasonik untuk meningkatkan yield gingerol dalam proses ekstraksi. Beberapa variabel yang dipelajari pada penelitian ini yaitu waktu ekstraksi dengan variasi 30, 60, 90, dan 120 menit. Selain itu, juga diamati pengaruh metode ekstraksi solven dan ultrasonik dengan variasi frekuensi ultrasonik 40 dan $50 \mathrm{kHz}$. Variabel tetap adalah pelarut etanol $70 \%$ (V/V) dan suhu proses 50 
${ }^{\circ} \mathrm{C}$. Ekstrak gingerol yang dihasilkan kemudian dipisahkan dari solven menggunakan rotary vacuum evaporator pada tekanan $350 \mathrm{mmHg}$. Analisis sampel secara kualitatif dilakukan menggunakan kromatografi lapis tipis (KLT) dan scanning electron microscope (SEM), sedangkan analisis secara kuantitatif kandungan gingerol yang dihasilkan menggunakan instrumentasi high performance liquid chromatography (HPLC) merek Waters Alliance e2695 dengan kolom X-Terra RP18 $100 \times 4,6$ mm, 5 mm. Hasil penelitian menunjukan tenaga ultrasonik berpengaruh secara signifikan terhadap hasil yang diperoleh dengan yield paling tinggi adalah 24,71\% pada tenaga ultrasonik $50 \mathrm{kHz}$ dengan waktu ekstraksi 120 menit.

Kata kunci:jahe; HPLC; rimpang; SEM; Soxhlet

\section{Introduction}

As a tropical country, Indonesia is very suitable for rhizome plants such as red ginger (Zingiber officinale var. Rubrum) (SMD, 2015). This plant is characterized by layered tubers, 4-5 cm in diameter and orange to red (Wicaksono, 2015). In fresh ginger, the primary polyphenols are gingerols with a composition of about 4-8\% (Lestari \& Lestari, 2009). However, harvest time, environment, and soil conditions greatly influence this composition (Nhestricia, 2017; Widiya, et al., 2019). Gingerol is the non-volatile component in ginger that contributes to its spicy taste (Wicaksono, 2015). This substance can provide pharmacological and physiological effects such as anti-inflammatory, analgesic, anti-carcinogenic, and antibacterial. (Levita, et al., 2018; Mao, et al., 2019). Moreover, red ginger is widely used as traditional medicine for a headache reliever, relieves swelling, menstrual pain, diuretic, stimulant, and diarrhea (Aryanta, 2019; Prakoeswa, et al., 2020).

Generally, the active components in plant rhizomes are separated by solvent extraction at an operating temperature corresponding to the solvent's boiling point. Unfortunately, gingerols can turn into shogaols at high temperatures (Fuadi, 2012). Therefore, alternative extraction methods are required, such as decreasing temperatures and less time-consuming techniques (Mane, et al., 2015). Recently, a new technique has been developed for ultrasonic-assisted solid-liquid extraction (Fuadi, 2012).

Ultrasonic-assisted extraction has the advantage over solvent extraction methods. It uses less solvent and shorter time (Shital, et al., 2018; Herliati, et al., 2020). In addition, ultrasonic waves propagating in a liquid medium produce cavitation bubbles that hit and damage the cell walls so that, at the same time, the active compounds in the cells have the opportunity to be extracted out (Siqhny, et al., 2020). A previous study was ultrasonication-assisted extraction to separate oleoresin in ginger (Fuadi, 2012). They used ethanol solvent with temperatures ranging from $3060{ }^{\circ} \mathrm{C}$ and an ultrasonic frequency of $42 \mathrm{kHz}$. Unfortunately, the results of this study are not satisfactory both in terms of low yield and time-consuming which is $7.434 \%$ within 4 hours. Another study also performed ultrasonic-assisted extraction to isolate curcumin in turmeric (Shital, et al., 2018). They reported that ethanol gave the best results among several solvents used: ethanol, methanol, and acetone. Moreover, it was also reported that the ultrasonic frequency of $33 \mathrm{kHz}$ gave a higher yield than 
conventional extraction even though the yield of $5.1 \%$ was still not satisfactory. Therefore, the ultrasonic-assisted extraction method is still interesting to study using a more extensive frequency range.

Previous studies used dry ginger powder with a size of up to 40 mesh. The ginger powder is mixed with ethanol as a solvent in a ratio of 1:3 (Fuadi, 2012). Maceration of raw materials with solvent is a pre-treatment before applying ultrasonic power (Kimthet, et al., 2017; Mane, et al., 2015; Nelly, et al., 2017; Shital, et al., 2018). It intends to apply mechanical stress to the cell to produce a cavity in the sample. Cell damage can cause the compound's solubility in the solvent to increase and increase the extraction yield (Fuadi, 2012; Mane, et al., 2015; Nelly, et al., 2017).

This study aimed to investigate the effect of ultrasonic-assisted extraction on the amount of Gingerol extracted from red ginger. Variables studied were extraction time (30, 60, 90 and 120 minutes), ultrasonic frequency (40 and $50 \mathrm{kHz}$ ), solvent ratio (ethanol:water; 70:30; v/v), and a temperature of $50^{\circ} \mathrm{C}$

\section{Research Methodology}

\subsection{Materials}

Fresh red ginger was obtained from the farmers in Bogor, Indonesia. The chemicals and reagents used in this research such as ethanol 96\% (v/v) for sample preparation, meanwhile technical grade of ethanol $70 \%$ (v/v) (J.T. Baker Chemical Company) were used for extraction process; acetonitrile, chloroform, methanol 95\% (v/v) also used for the mobile phase of HPLC, and external Zingiber officinale standard were supplied by Merck Supelco Sigma-Aldrich (Germany).

\subsection{Procedures}

Fresh red ginger was washed before being used and prepared following this procedure: (i) sliced with a thickness of approximately 6 $7 \mathrm{~mm}$, (ii) dried in an oven at a temperature of $50{ }^{\circ} \mathrm{C}$ for 1 hour to remove most of the water, (iii) crushed and sieved the dry ginger to pass 40 mesh. The powder was stored at room temperature until required. All the extractions were conducted using $50 \mathrm{~g}$ of ginger powder mixed with $200 \mathrm{~mL}$ of ethanol $70 \%(\mathrm{v} / \mathrm{v})$ as a solvent.

Ultrasonic-assisted extraction was carried out using Branson 5510 Ultrasonic Liquid Processor fitted with a stainless steel probe operating at 40 and $50 \mathrm{kHz}$. The probe was immersed in $200 \mathrm{~mL}$ of extraction solvent containing $50 \mathrm{~g}$ of ginger powder in a $250 \mathrm{~mL}$ beaker. The beaker was then placed in a $3 \mathrm{~L}$ bath filled with water to control temperature during sonication. Then the temperature was maintained at $50 \pm 2{ }^{\circ} \mathrm{C}$ for each experiment. Samples were removed at regular time intervals (30,60 90, and $120 \mathrm{~min})$, filtered and separated from the solvent using a vacuum evaporator at operating condition $350 \mathrm{mmHg}$ and a temperature of $50^{\circ} \mathrm{C}$. The SEM test was carried out on the cake obtained at the filtration stage.

Additionally, this experiment used solvent extraction as a control to see the effect of ultrasonication assistance on the level of extracted gingerol. For solvent extraction, a mixture of $50 \mathrm{~g}$ of ginger powder and $200 \mathrm{~mL}$ of $70 \%$ ethanol $(\mathrm{v} / \mathrm{v})$ was stirred using a shaker for 30, 60, 90, and 120 minutes, respectively. So, there are four variations of the test sample. The mixture was then stored for 24 hours at room temperature to ensure maximum extraction. After that, the mixture was filtered with filter paper to separate the 
filtrate from the cake. The filtrate obtained was then fed into a vacuum rotary evaporator at operating conditions of $350 \mathrm{mmHg}$ and a temperature of $50^{\circ} \mathrm{C}$ to separate the solvent so that a thick extract is obtained. At the same time, the cake was prepared for the SEM Test.

\subsection{Analysis}

Gingerol content determination was performed using HPLC Waters Alliance e2695, equipped with Column X Terra RP 18 (particle size five $\mu \mathrm{m}, 100 \times 4.6 \mathrm{~mm}$ ). The HPLC uses chromatographic separation of liquid mixtures with a high boiling point (Sun, et al., 2017). To calculate the gingerol content in the product, the following equation was used in the literature (Kimthet, et al., 2017):

$$
\% \text { Yield }=\frac{W_{\text {extract }} x V_{\text {total extract }}}{W_{\text {raw materials }}} \times 100
$$

where $W_{\text {extract }}$ is the weight of the extract in 1 $\mathrm{mL}$ of sample $(\mathrm{g} / \mathrm{mL}), V_{\text {total }}$ extract is the total volume of extract $(\mathrm{mL}), W_{\text {raw materials }}$ is the weight of extracted ginger powder. Experimental data were taken triple each.

A scanning electron microscope (SEM) test was carried out to observe the effect of ultrasonic energy on the morphology of ginger cells. SEM works to form an image on the surface of the specimen microscopically. Then, an electron beam with a diameter of 5$10 \mathrm{~nm}$ pointed at the specimen. The electron beam interaction with the specimen results in electron beam backscattering, X-rays, secondary electrons, and electron absorption (XiaoyanZhao, et al., 2010).

\subsection{Statistical Analysis}

A two-way analysis of variance was performed using a general linear model (GLM - SPSS version 19, SPSS Inc., Chicago). The following equation was used to calculate each observation, Total Sum of Squares (TSS), Sum of Squares of Rows (SSR), Sum of Squares of Columns (SSC), and Sum of Interaction Squares (SIS).

$$
\begin{aligned}
X_{i j k} & =\mu+\alpha_{i}+\beta_{j}+(\alpha \beta)_{i j}+\varepsilon_{i j k} \\
\text { TSS } & =\text { Total Sum of Squares } \\
& =\sum_{i=1}^{r} \sum_{j=1}^{c} \sum_{k=1}^{n} x_{i j k}^{2}-\frac{T \ldots{ }^{2}}{r c n} \\
\text { SSR } & =\text { Sum of Squares of Rows } \\
& =\frac{\sum_{i=1}^{r} T_{i . .}^{2}}{c n}-\frac{T \ldots{ }^{2}}{r c n} \\
\text { SSC } & =\text { Sum of Squares of Columns } \\
& =\frac{\sum_{j=1}^{c} T_{i . .}^{2}}{r n}-\frac{T \ldots{ }^{2}}{r c n} \\
\text { SIS } & =\text { Sum of Interaction Squares } \\
& =\sum_{i=1}^{r} \sum_{j=1}^{c} \sum_{k=1}^{n} x_{i j k}^{2}-\frac{T \ldots{ }^{2}}{r c n} \\
\text { SSE } & =\text { Sum of Squares Error } \\
& =\text { TSS }- \text { SSR }- \text { SSC }- \text { SIS }
\end{aligned}
$$

where $i=1,2, \ldots, j=1,2, ., \quad$ and $\mathrm{k}=1,2, . ., \mathrm{n} ; \quad x_{\mathrm{ijk}}$ : Observation of the factor treatment Row-i and Column $j$ factor treatment; $\mu$ : general average; $\alpha_{i}$ : the effect of the factor treatment row- $i ; \beta_{j}$ : the effect of the factor treatment column $\mathrm{j}_{\mathrm{i}}(\alpha \beta)_{\mathrm{ij} ;}$ : the effect of the interaction between the treatment of the factor treatment Row-i with the treatment factor Column-j; $\varepsilon_{\mathrm{ij}}$ : random error of row-i and column-j. The hypothesis to be tested is the effect of time variation and extraction method and the effect of the interaction between the two variables as follows:

a. $H_{\circ}: \alpha_{1}=\alpha_{2}=\ldots=\alpha_{r}=0$ (there is no effect of extraction time)

$\mathrm{H}_{1}$ : not all $\alpha_{i}=0$ (there is an effect of extraction time)

b. $H_{\circ}: \beta_{1}=\beta_{2}=\ldots=\beta_{c}=0$ (there is no effect of the extraction method) 
$\mathrm{H}_{1}$ : not all $\beta_{\mathrm{i}}=0$ (there is an effect of the extraction method)

c. $H_{\circ}:(\alpha \beta)_{11}=(\alpha \beta)_{12}=\ldots=(\alpha \beta)_{\mathrm{rc}}=0$ (no interaction effect)

$\mathrm{H}_{1}$ : not all $\alpha_{\mathrm{i}}=0$ (there is the influence of the interaction between variables)

\section{Results and Discussion}

Sample analysis in this study was carried out using HPLC. Before sample analysis, validation was performed by injecting the standard solution six times. The method is declared valid if the Relative Standard Deviation (RSD) area is $\leq 2 \%$. The validation results are shown in Table 1.

Table 1. System Suitability Test

\begin{tabular}{|c|c|c|c|}
\hline No & Sample Nama & $\begin{array}{l}\text { Retention } \\
\text { Time }\end{array}$ & Area \\
\hline 1 & $\begin{array}{l}\text { STD Ext. Zingiber } \\
\text { Officinale-1 }\end{array}$ & 1.5 & 196148 \\
\hline 2 & $\begin{array}{l}\text { STD Ext. Zingiber } \\
\text { Officinale-2 }\end{array}$ & 1.5 & 195684 \\
\hline 3 & $\begin{array}{l}\text { STD Ext. Zingiber } \\
\text { Officinale-3 }\end{array}$ & 1.5 & 195642 \\
\hline 4 & $\begin{array}{l}\text { STD Ext. Zingiber } \\
\text { Officinale- } 4\end{array}$ & 1.5 & 194837 \\
\hline 5 & $\begin{array}{l}\text { STD Ext. Zingiber } \\
\text { Officinale-5 }\end{array}$ & 1.5 & 194774 \\
\hline \multirow[t]{3}{*}{6} & $\begin{array}{l}\text { STD Ext. Zingiber } \\
\text { Officinale- } 6\end{array}$ & 1.5 & 196182 \\
\hline & & Average & $195545 \pm 615.43$ \\
\hline & & $\%$ RSD & 0.31 \\
\hline
\end{tabular}

The HPLC method identifies gingerol by comparing the retention time of the measured test sample with the standard (Hirjani, et al., 2018). The retention time is when it takes for the substrate to pass through the column to the detector. Thus, the retention time is from the sample into the column until the maximum reading at the detector. The standard gingerol retention time is 1.453 minutes, as shown in Figure 1.

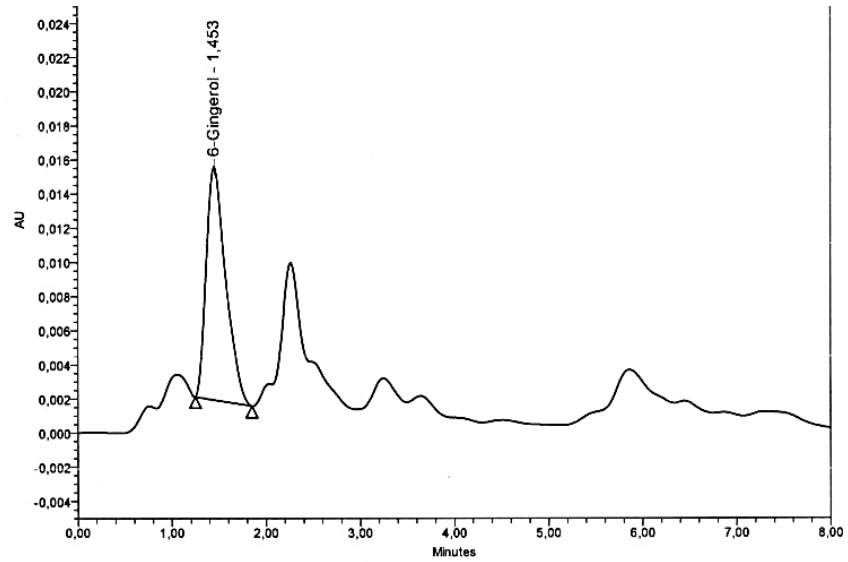

Figure 1. Chromatogram of the gingerol standard

Figure 2 is a chromatogram of the ultrasonic extraction test sample with $50 \mathrm{kHz}$ at 120 minutes. It shows that the retention time of the test sample for the gingerol compound appears at 1.445 minutes. The retention time between the standard sample and the test sample appears at very close minutes. This result provides positive confirmation that there is a gingerol compound in the test sample results of the study.

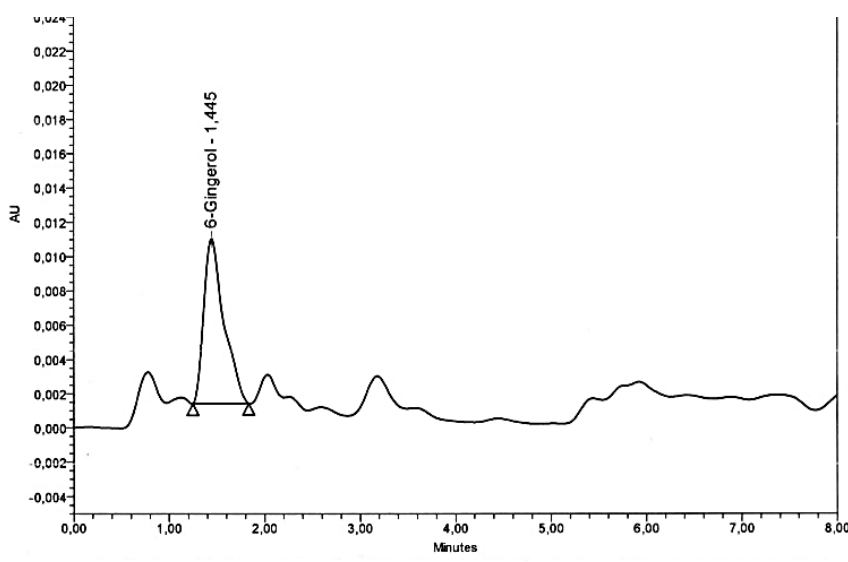

Figure 2. Gingerol chromatogram in ultrasonicassisted extraction at $50 \mathrm{kHz}, 120$ minutes 
Table 2 and Figure 3 show that gingerol yield increases with increasing ultrasonic frequency and extraction time. In other words, ultrasonic-assisted extraction gives better results compared to solvent extraction methods for all test samples. These results strongly agree with the previous report (Fuadi, 2012; Hapsari, et al., 2015; Mane, et al., 2015; Nelly, et al., 2017). The best results in this study were at $50 \mathrm{kHz}$ ultrasonic frequency for 120 minutes, namely a $24.71 \%$ yield, which is better than the previous similar method.

Table 2. Gingerol yield comparison between ultrasonic and solvent extraction $(n=3 \pm S D)$

\begin{tabular}{cccc}
\hline \multirow{2}{*}{$\begin{array}{c}\text { Time } \\
\text { (minute) }\end{array}$} & $\begin{array}{c}\text { Solvent } \\
\text { Extraction }\end{array}$ & \multicolumn{2}{c}{$\begin{array}{c}\text { Ultrasonic-assisted } \\
\text { extraction }\end{array}$} \\
\cline { 3 - 4 } & & $40 \mathrm{kHz}$ & $50 \mathrm{kHz}$ \\
\hline 30 & $9.12 \pm 0.028$ & $17.80 \pm 0.163$ & $18.24 \pm 0.092$ \\
60 & $11.42 \pm 0.099$ & $18.71 \pm 0.057$ & $18.79 \pm 0.120$ \\
90 & $11.49 \pm 0.035$ & $20.10 \pm 0.049$ & $21.68 \pm 0.106$ \\
120 & $12.66 \pm 0.021$ & $23.92 \pm 0.332$ & $24.71 \pm 0.085$ \\
\hline
\end{tabular}

SEM test was performed to confirm the effect of the ultrasonic method on the ginger sample, morphological analysis of the extracted cakes (XiaoyanZhao, et al., 2010). Based on Figure 4, the solvent extraction shows that the ginger pulp cells are still smooth and do not have pores. However, in samples by ultrasonic extraction, there were cracks and pores with a rough cell structure. These micrographs show damaged surface morphology of ginger due to ultrasonic energy. This fact is because the ultrasonic power exerts mechanical pressure on the ginger tissue to damage the cells. Therefore, cell damage impacts increasing the solubility of gingerol in the solvent so that the extraction yield increases. In addition, Figure 4.b is a microgram with a magnification of $3,000 x$, i.e., ultrasonic extraction with $50 \mathrm{kHz}$ at an extraction time of 120 minutes, showing the most severe cell damage. This appearance confirms that ultrasonic power has a significant effect on the extraction yield. These results are very close to previous researchers (Fuadi, 2012; Kimthet, et al., 2017; Zaibunnisa, et al., 2016).

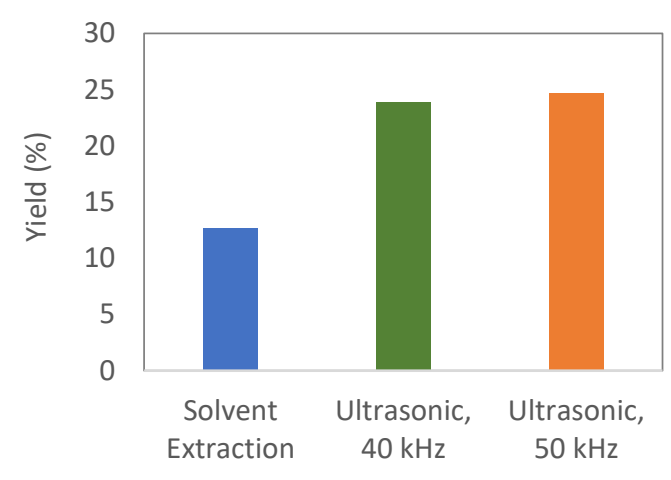

Figure 3. Yield comparison between solvent and ultrasonic method at $120^{\prime}$

In order to see the effect of the extraction method and the time variation used during the experiment (in this case, the amount of gingerol extracted), a two-way analysis of variance was performed using a general linear model (GLM - SPSS version 19, SPSS Inc., Chicago). In this study, the extraction time (30, 60,90 , and $120 \mathrm{~min}$ ) is the row factor with $r$ treatment (level), and the extraction method (solvent extraction, $40 \mathrm{kHz}$, and $50 \mathrm{kHz}$ ultrasonic power) is the column factor with $\mathrm{c}$ treatment (level). Data displayed in Table 3 are the mean $(n=3) \pm$ standard deviation (SD), which were calculated using functions in Microsoft Excel ${ }^{(R)}$. Table 3 presents the results of the ANOVA test.

Table 3 also shows that the $F$ count of the column is 1956,475 while compared to $F(\alpha, r$ $1, r c(n-1))=F(0.05,3,12)$ is 3.49. Thus, $F$ count $>\mathrm{F}$ table, then $\mathrm{HO}$ is rejected, meaning 
that extraction time affects gingerol yield. Besides that, the result of $\mathrm{F}$ count of the row is 14230.133 compared to $F(\alpha, c-1, r c(n-1))=$ $F(0.05,2,12)$ is 3.89. Thus, $F$ count $>F$ table, then $\mathrm{HO}$ is rejected, meaning that the extraction method affects gingerol yield. Based on the interaction test, the F count of lines is 143.217 compared to $F(\alpha,(r-1)(c-1)$, $\mathrm{rc}(\mathrm{n}-1))=\mathrm{F}(0.05,6,12)$ is 3.00 . Thus, $\mathrm{F}$ count $>F$ table, then $\mathrm{HO}$ is rejected, meaning there is an interaction between time and the extraction method used on gingerol yield.

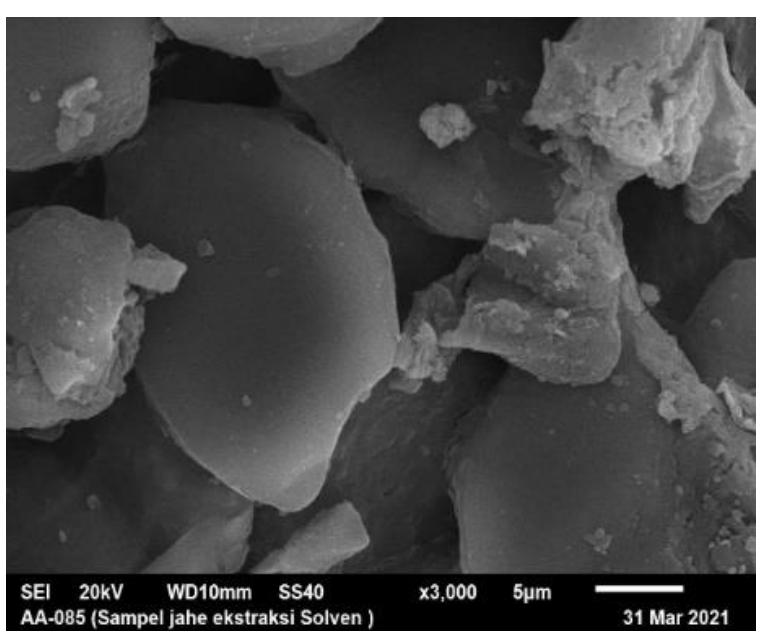

(a)

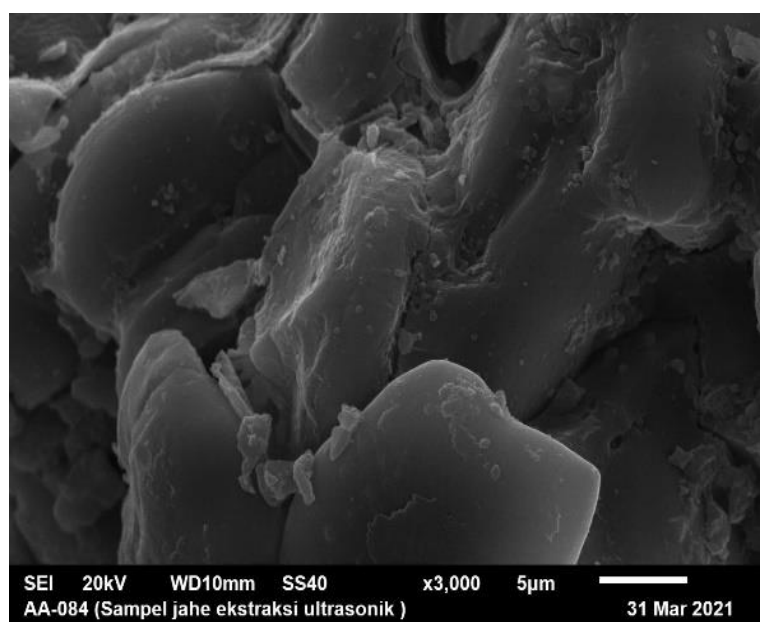

(b)

Figure 4. SEM test results at $120^{\prime}, 50 \mathrm{kHz}$ (a) Solvent extraction at $3,000 \mathrm{x}$ magnification (b) Ultrasonic extraction with 3,000x magnification
Table 3. Two-Way ANOVA testing results with interaction

\begin{tabular}{cccccc}
\hline $\begin{array}{c}\text { Variation } \\
\text { Source }\end{array}$ & $\begin{array}{c}\text { Degree of } \\
\text { freedom }\end{array}$ & $\begin{array}{c}\text { Total } \\
\text { Squared } \\
(\mathrm{TS})\end{array}$ & $\begin{array}{c}\text { Middle } \\
\text { Square } \\
(\mathrm{MS})\end{array}$ & $\mathrm{F}_{\text {count }}$ \\
\hline Row (R) & 3 & 95.965 & 31.988 & $\mathrm{~F} 1=$ & 1956.475 \\
Column (C) & 2 & 465.325 & 232.663 & $\mathrm{~F} 2=14230.133$ \\
Interaction (I) & 1.5 & 14.050 & 2.342 & $\mathrm{~F} 3=$ & 143.217 \\
Error & 12 & 0.196 & 0.016 & & \\
\hline
\end{tabular}

\section{Conclusions}

A series of experiments, observations, and data analysis of red ginger extraction products shows that the solvent extraction method produced $12.66 \%$ gingerol content. Meanwhile, the ultrasonic extraction method can increase the yield up to $24.71 \%$. This result proves that the ultrasonic method has a significant effect, almost two times more than the solvent extraction method. SEM testing also confirms that the extraction of ultrasonicassisted causes damage to ginger cell tissue, increasing gingerol yield. In addition, the twoway ANOVA test showed that the value of $F$ count $>\mathrm{F}$ table means that time and extraction method affect gingerol yield.

\section{Acknowledgments}

The author acknowledges the Jayabaya University internal grant scheme "Ekstraksi Gingerol dalam Rimpang Jahe Merah (Zingiber Officinale varietas Rubrum) dengan Metode Ultrasonik" with research grant number: 71.004/KONTRAK PENELITIAN/FTIUJ/XII/2020. 


\section{References}

Aryanta, I. W. R., 2019. Manfaat Jahe Untuk Kesehatan. Widya Kesehatan, 1(2), p. 3943.

Fuadi, A., 2012. Ultrasonik Sebagai Alat Bantu Ekstraksi Oleoresin Jahe. Jurnal Teknologi, pp. 14-21.

Hapsari, F., Prasetyo, I. \& Budhijanto, W., 2015.

Evaluasi Efek Pre-treatment Ultrasonik Pada Proses Hidrolisis Enzimatis Ampas Tahu. Jurmal Rekayasa Proses, 9(2), pp. 6570.

Herliati, R., Arini, S. F. \& Utomo, V., 2020.

Tannins Extraction of Tea Leaves by Ultrasonic Method: Comparison with The Conventional Method. Jurnal Teknologi, 8(1), pp. 84-95.

Hirjani, H., Mudasir, M. \& Pranowo, H. D., 2018. Prediction of High Performance Liquid Chromatography Retention Time for Some Organic Compounds Based on Ab initio QSPR Study. Acta. Chim. Asiana, 1(1), pp. 24-29.

Kimthet, C., Wahyudiono, Kanda, H. \& Goto, M., 2017. Comparison of Conventional and Ultrasound Assisted Supercritical Carbon Dioxide Extraction of Curcumin from Turmeric (Curcuma longa L.). Engineering Journal, pp. 53-65.

Lestari, T. P. \& Lestari, N., 2009. Analisis Senyawa Kimia Pada Tiga Jenis Jahe Dan Penggunaannya Tiga Jenis Jahe Dan Penggunaannya. Jurnal Riset Teknologi Industri, 3(6), pp. 32-38.

Levita, J. et al., 2018. Pharmacokinetics of 10-gingerol and 6-shogaol in the plasma of healthy subjects treated with red ginger (Zingiber officinale var. Rubrum) suspension. Biomedical Reports, 9(6), pp. 474-482.
Mane, S., Bremner, D. H., Clarke, A. T. \& Lemos, M. A., 2015. Effect of ultrasound on the extraction of total anthocyanins from Purple Majesty potato. Ultrasonics Sonochemistry, pp. 509-515.

Mao, Q.-Q.et al., 2019. Bioactive Compounds and Bioactivities of Ginger (Zingiber officinale Roscoe). Foods, 8(6), p. 185.

Nelly, M. T., Ayora-Talavera, T. \& Hugo, E. A., 2017. Ultrasound assisted extraction for the recovery of phenolic compounds from vegetable sources. Agronomy, pp. 2-19.

Nhestricia, N., 2017. Pengaruh Konsentrasi Oleoresin Dan Komposisi Bahan Penyalut Terhadap Karakteristik Mikrokapsul Oleoresin Jahe Emprit (Zingiber Officinale) Dengan Metoda Spray Drying. Fitofarmak, 7(1), pp. 44-53.

Prakoeswa, S. A., Tanowidjaya, R. \& Suryaningsih, D. R., 2020. Propagasi Dan Biosintesis Kandungan Gingerol, Shogaol Dan Zingerone (Ginger Oil) Dari Kalus Jahe Emprit (Zingiber Majus R.) Dengan Perlakuan Jenis Media Dan Macam Karbohidrat. Jurnal Teknik Kimia, 14(2), pp. 45-50.

Shital, P. et al., 2018. Ultrasound assisted extraction of curcumin. Asian J. Dairy \& Food Res, pp. 250-252.

Siqhny, Z. D., Azkia, M. N. \& Kunarto, B., 2020. Karakteristik Nano Emulsi Ekstrak Buah Parijoto (Medinilla speciosa Blume). Jurnal Teknologi Pangan dan Hasil Pertanian, 15(1), pp. 1-10.

SMD, R., 2015. Kesiapan Teknologi Mendukung Pertanian Organik Tanaman Obat:. Perspektif, 6(2), pp. 76-84.

Sun, L. et al., 2017. A simple method for HPLC retention time prediction: linear calibration using two reference substances. Chinese Medicine, 12(16), pp. 1-12. 
Wicaksono, A. P., 2015. Pengaruh Pemberian Ekstrak Jahe Merah (Zingiber Officinale) terhadap Kadar Glukosa Darah Puasa dan Postprandial pada Tikus Diabetes. Majority, 4(7), p. 97-102.

Widiya, M., Jayati, R. D. \& Fitriani, H., 2019. Karakteristik Morfologi dan Anatomi Jahe (Zingiber Officinale) Berdasarkan Perbedaan Ketinggian Tempat. Bioedusains J. Pendidik. Biol. dan Sains, 2(2), pp. 60-69.

XiaoyanZhao, et al., 2010. Surface characterization of ginger powder examined by X-ray photoelectron spectroscopy and scanning electron microscopy. Colloids and Surfaces $B$ : Biointerfaces, 79(2), pp. 494-500.

Zaibunnisa, A. H., Siti, H. M. S., Khudzir, I. \& Nooraain, H., 2016. Quality Parameters Of Curcuma Longa L. Extracts By Supercritical Fluid Extraction (Sfe) And Ultrasonic Assisted Extraction (UAE). Malaysian Journal Of Analitical Sciences, pp. 626 632. 